\title{
Antioxidant activity and resveratrol content in wines the national origin
}

\begin{abstract}
Wines are an important source of resveratrol and polyphenols, in this sense this work has focused on the determination of antioxidant activity and resveratrol content in wines of origin. The different wines analyzed exhibited strong antioxidant activity for the ABTS and DPPH tests, which are in the ranges of 2.123 to $25.097[\mu \mathrm{mol} / \mathrm{ml}]$ and 2.348 to 17.138 $[\mu \mathrm{mol} / \mathrm{ml}]$ for red wines respectively, while for white wines the ranges they are 0.793 to $2.604[\mu \mathrm{mol} / \mathrm{ml}]$ and 0.419 to $3.07[\mu \mathrm{mol} / \mathrm{ml}]$ respectively. Regarding the quantification and presence of trans-resveratrol, this was confirmed in most of the wines analyzed, with concentrations ranging between 0.77 and $3.25[\mathrm{ppm}]$ in red wines. As for white wines, these oscillate in the range of 0.18 to 0.69 [ppm]. Analyzing and comparing the results obtained in wines of origin, we observe that red wines have a good content of resveratrol and that in turn comparing results of other authors, we observe that the content of resveratrol in wines of origin is within the bibliographic range, both for red and white wines.
\end{abstract}

Keywords: wine, antioxidant activity, resveratrol
Volume 10 Issue 6 - 2021

\author{
Callisaya A Juan Carlos, ${ }^{3}$ Arteaga SM del \\ Carmen, ${ }^{3}$ Taquichiri T Marco A,' Gutiérrez \\ Barea Pastor, ${ }^{2}$ Paco Sarzuri Joel, ${ }^{2}$ Solano \\ Iván T, ${ }^{3}$ Díaz de Oropeza Rosario, ${ }^{3}$ Vargas M \\ Mariela ${ }^{3}$ \\ 'Director of the Physics Department, Faculty of science and \\ technology, UAJMS, Bolivia \\ ${ }^{2}$ Research Teachers, Department of Physics, Faculty of science \\ and technology, UAJMS, Bolivia \\ ${ }^{3}$ Researchers Laboratory of Bioactive Compounds, UAJMS, \\ Bolivia
}

\section{Correspondence: Callisaya A Juan Carlos, Researchers Laboratory of Bioactive Compounds, UAJMS, Bolivia,} Email jkallisaya34@gmail.com

Co-correspondence: Taquichiri T Marco A, Director of the Physics Department, Faculty of science and technology, UAJMS, Bolivia,Email iisoc@gmail.com

Received: November 14, 2021 | Published: November 22, 2021

\section{Introduction}

In the last decade, the study of chemical components, mainly the content of polyphenols, has aroused great interest as an antioxidant Several studies show that they have a protective effect against cardiovascular diseases, some types of cancer, coronary heart diseases, diabetes, rheumatic arthritis, Parkinson's, Alzheimer's, slowing down the cellular aging process and for their antioxidant properties, which have been proven in studies in animals and humans. ${ }^{1,2}$

Currently, this group of phytochemical compounds has a great nutritional interest due to its contribution to the maintenance of human health and they are also related to the sensory quality of foods of plant origin, both fresh and processed. Many of these beneficial properties described in foods of plant origin, mainly associated with antioxidant activity and antinutritive properties of these compounds, are related to the presence and content of polyphenols.

Wine is one of the dietary sources of polyphenols with the greatest abundance and diversity of phenolic compounds, among these compounds are flavonoids and numerous phenolic acids that have been shown to have multiple therapeutic applications mainly related to antioxidant activity. The moderate and regular consumption of wine is responsible for these beneficial health effects. ${ }^{3}$

The polyphenol content in wine can be strongly influenced not only by vine varieties and their cultivation, but also through their extraction during the winemaking process, transport and storage. During the wine aging process, the amount of polyphenols present in wine, particularly anthocyanins, can be directly affected by several factors including $\mathrm{pH}$, light, temperature, oxygen, enzymes, ascorbic acid, saccharides, sulfur dioxide or sulfite and metallic co-pigments. ${ }^{4,5}$
Therefore, the composition of antioxidants in the samples are quite complex, generally involving multiple reactions and mechanisms, so that no test will accurately reflect all the antioxidants in a complex mixture or system, being different tests are necessary to quantify the antioxidant activity.

Another important compound contained in wine is resveratrol (Figure 1) (3, 5, 4 -trihydroxystilbene: $\left.\mathrm{C}_{14} \mathrm{H}_{12} \mathrm{O}_{3}\right)$ which is a stilbene phytoalexin and is considered a very important antioxidant compound found in certain foods and plants. ${ }^{6}$<smiles>Oc1ccc(CCc2cc(O)cc(O)c2)cc1</smiles>

Trans-resveratrol<smiles>Oc1ccc(/C=C\c2cc(O)cc(O)c2)cc1</smiles>

Cis-resveratrol
Figure I Chemical structure of trans-resveratrol and cis-resveratrol or 3,4 ', 5-trihydroxystilbene.

Resveratrol is a radical scavenger and inhibits the risk of cardiovascular diseases, acting as a powerful antioxidant, both through the classical uptake of hydroxyl radicals and through a novel glutathione sparing mechanism. 
During the attack of Botrytis cinerea and UV solar radiation, the plant, as a defense response, forms a resveratrol barrier. ${ }^{9,10}$ Recently, several studies showed that in high doses of resveratrol, it can extend life in some studies in invertebrates and prevent early mortality in mice fed a high-fat diet. ${ }^{1}$

Wine, especially red, is the main source of resveratrol in the human diet. Already, for several years the scientific community carried out several studies on a phenomenon known as "the French paradox", ${ }^{17}$ where the residents of Toulouse (France) had a low incidence of cardiovascular diseases, despite a diet prone to such events. The study showed that grape skins ${ }^{18,19}$ and certain wines ${ }^{20}$ contained transresveratrol, a compound that is present in red wine and is widely consumed in the diet.

In Bolivia, the largest wine production is concentrated in a very particular way in the department of Tarija, a region located in the south of Bolivia between 1750 and 2800 meters above sea level, being the highest vineyards in the world. Therefore, the present work aims to determine and compare the total antioxidant capacity "TAC" using the spectrophotometric method for the ABTS + and DPPH' tests and quantification of the resveratrol content by the HPLC method, in wines produced in this region of Bolivia.

\section{Materials and methods}

\section{Chemical reagents for the measurement of antioxidant activity}

ABTS [2, 2'-azinobis (3-ethylbenzothiazoline-6-sulphonic acid)], potassium persulfate, trolox (6-hydroxy-2, 5, 7, 8-tetramethylchroman2-carboxylic acid, 97\%), TPTZ (2, 4, 6-trypyridyl-s-triazine). DPPH (2,2-diphenyl-1-pidrylhydrazyl), ferric chloride is purchased from
ICN Biomedicals Inc. (Costa Mesa, CA, USA), acetic acid (glacial pa) and sodium acetate from BDH Chemicals Ltd. (Poole, UK).

\section{Chemical reagents for the quantification of resveratrol}

Resveratrol was purchased from ChromaDex (Irvine, CA, USA), Acetonitrile HPLC grade (Solvent A) and HPLC grade Formic Acid (Solvent B).

\section{Wine samples}

The tests were carried out on red and white wines (Table 1) produced in the department of Tarija and 4 wines from different origins, which were selected according to vintage. These wines were acquired from outlets in the city of Tarija, which are usually consumed by the population of the region. The samples were stored at room temperature and in the dark until the moment of analysis.

\section{Measurements of antioxidant capacity}

Data are reported as mean and standard deviation (SD) for nine replicates measured over 3 days for TAC (ABTS and DPPH).

\section{ABTS method 12,13}

This assay uses an aqueous solution of 2, 2-azinobis (ethylbenzothiazoline-6-sulfonate) (ABTS) $(7 \mathrm{mM})$ oxidized with $2.45 \mathrm{mM}$ potassium persulfate. The ABTS solution is diluted with phosphate buffered saline $\mathrm{pH}=7.4$ to an absorbance of $0.7 \pm 0.02$ at $734 \mathrm{~nm}$ on a UV-Vis spectrophotometer. The standard calibration curve is constructed with trolox at different concentrations. An aliquot of each sample is mixed with $1 \mathrm{~mL}$ of the ABTS cation radical solution in a tube, and its absorbance is then read. The decay in absorbance caused by the addition of sample is compared to that of the standard curve where the trolox is used.

Table I Identity and origin of the analyzed wines

\begin{tabular}{lllll}
\hline CODE & TRADEMARK & ORIGIN & VARIETY & YEAR \\
\hline VT-I & CAMPOS DE SOLANA & TARIJA & CLASSIC RED WINE & 2014 \\
VT-2 & ARANJUEZ & TARIJA & RED TERRUÑO & 2013 \\
VT-3 & KOHLBERG & TARIJA & FINE RED WINE & 2014 \\
VB-I & ARANJUEZ & TARIJA & GREATWHITEWINE & 2013 \\
VB-2 & ARANJUEZ & TARIJA & WHITETERRUÑO & 2013 \\
VB-3 & CAMPOS DE SOLANA & TARIJA & CLASSICWHITEWINE & 2013 \\
VB-4 & KOHLBERG & TARIJA & FINEWHITEWINE & 2014 \\
VT-4 & CAMPOS DE SOLANA & TARIJA & CABERNET SAUVIGNON & 2012 \\
VT-5 & KOHLBERG & TARIJA & CABERNET SAUVIGNON & 2012 \\
VT-6 & ARANJUEZ & TARIJA & CABERNET SAUVIGNON & 2012 \\
VT-7 & LA CONCEPCION & TARIJA & CABERNET SAUVIGNON & 2013 \\
VT-8 & I75O & SANTA CRUZ & CABERNET SAUVIGNON & 2013 \\
VT-9 & KOHLBERG & TARIJA & SYRAH & 2012 \\
VT-10 & SAUSINI & TARIJA & MERLOT & 2013 \\
VT-II & LA CONCEPCION & TARIJA & MERLOT & 2012 \\
VT-I2 & ARANJUEZ & TARIJA & TANNAT & 2012 \\
VB-5 & LA CONCEPCION & TARIJA & SAUVIGNON BLANC & 2013 \\
VT-13 & LA CASONA DE MOLINA & CAMARGO & CABERNET SAUVIGNON & 2008 \\
\hline & & & & \\
\hline
\end{tabular}




\begin{tabular}{llllc}
\multicolumn{2}{l}{ Table Continued... } \\
\hline CODE & TRADEMARK & ORIGIN & VARIETY & YEAR \\
\hline VB-6 & LA CASONA DE MOLINA & CAMARGO & MISSIONARY & 2009 \\
VB-7 & LA CASONA DE MOLINA & CAMARGO & ALEXANDRIA MOSCATEL & 2014 \\
VT-I4 & 3 ZORROS & CAMARGO & VICCHOQUEÑA & \\
V & DOÑAVITA & TARIJA & WHITE CHOLERO \\
W & DOÑA VITA & TARIJA & RED CHOLERO & \\
VSA-T & SANTA ANA & ARGENTINA & CABERNET SAUVIGNON & 2012 \\
VSA-B & SANTA ANA & ARGENTINA & SYRAH & 2012 \\
VSC-T & SANTA CAROLINA & CHILE & CABERNET SAUVIGNON & 2012 \\
VSC-B & CASILLERO DEL DIABLO & CHILE & SYRAH & 2011
\end{tabular}

\section{DPPH method $^{14}$}

The DPPH reagent is prepared with ethanol until its absorbance is equal to $0.70 \pm 0.02$, for the reaction $1 \mathrm{~mL}$ of the reagent is prepared and $100 \mu \mathrm{L}$ of the sample is added, the absorbance is read in two times, initial time or zero and at 15 minutes according to a maximum peak scan found in the laboratory and measured at a wavelength of $519 \mathrm{~nm}$. Methods described by Peñarrieta et al., ${ }^{14-16}$.

\section{Quantification of resveratrol}

The HPLC ${ }^{15}$ methodology used in the present study is a modification of the methods described by Cristea et al. ${ }^{15}$ Resveratrol is quantified by comparison with the calibration curve of the external standard Resveratrol $99.99 \%$, in a range of $0.5 \mathrm{ppm}$ to $12 \mathrm{ppm}$, the samples are injected into the equipment, after filtering on acrodisks of Hydrophobic millex PTFE using Acetonitrile and Acetonitrile as mobile phase. Formic Acid $3.4 \mathrm{mM}$. The identification of the analyte is based on the comparison of the retention time "TR" and UV spectrum. The quantification of the resveratrol content in the wines was carried out under the following parameters:

\section{HPLC equipment}

High Resolution Liquid Chromatograph - Agilent technologies-1600.

\section{Solvents}

Acetonitrile (solvent A)
Formic Acid $3.4 \mathrm{mM}$ (Solvent B).

Flow rate: $0.8 \mathrm{ml} / \mathrm{min}$.

\section{Analysis of results}

The results of the evaluation of the antioxidant activity in the different wines analyzed exhibited strong antioxidant activity, which are shown in Table 2, Graph 1. The results of the statistical analysis for the antioxidant activity ABTS and DPPH are in the range of 2,123 at $25.097[\mu \mathrm{mol} / \mathrm{ml}]$ and 2.348 to $17.138[\mu \mathrm{mol} / \mathrm{ml}]$ for red wines respectively, while for white wines the ranges fluctuate from 0.793 to $2.604[\mu \mathrm{mol} / \mathrm{ml}]$ and 0.419 to $3.07[\mu \mathrm{mol} / \mathrm{ml}]$ respectively. These results show us that there are significant differences in the different wines evaluated, where red wines present higher antioxidant activity than white wines.
Rodríguez and García (2005), point out that red wines presented greater antioxidant capacity than white wines, in a study carried out to evaluate the antioxidant capacity in wines, using the radical method ABTS -+ , point out that it varies according to the following order: white $<$ pink $<$ red, these results are similar to those obtained in this work.

Table 2 Antioxidant activity in $\mathrm{X}$ prom $\pm \Delta \mathrm{X}$ wines

\begin{tabular}{lll}
\hline CODE & TAC ABTS $[\mu \mathrm{mol} / \mathrm{ml}]$ & TAC DPPH $[\mu \mathrm{mol} / \mathrm{ml}]$ \\
\hline VT-I & $3,392 \pm 0,0020$ & $3,864 \pm 0,0017$ \\
VT-2 & $2,499 \pm 0,0024$ & $2,799 \pm 0,0018$ \\
VT-3 & $2,123 \pm 0,0027$ & $2,348 \pm 0,0005$ \\
VB-I & $2,093 \pm 0,0010$ & $2,96 \pm 0,0024$ \\
VB-2 & $1,742 \pm 0,0010$ & $2,04 \pm 0,0015$ \\
VB-3 & $2,099 \pm 0,0017$ & $2,954 \pm 0,0022$ \\
VB-4 & $2,604 \pm 0,0022$ & $3,07 \pm 0,0009$ \\
VT-4 & $20,791 \pm 0,0018$ & $12,96 \pm 0,0019$ \\
VT-5 & $25,097 \pm 0,0035$ & $17,138 \pm 0,0012$ \\
VT-6 & $23,629 \pm 0,0018$ & $10,698 \pm 0,0012$ \\
VT-7 & $\mid 7,364 \pm 0,0021$ & $9,315 \pm 0,0011$ \\
VT-8 & $17,333 \pm 0,0021$ & $10,363 \pm 0,0016$ \\
VT-9 & $\mid 3,284 \pm 0,0003$ & $6,883 \pm 0,0017$ \\
VT-I0 & $21,823 \pm 0,0009$ & $13,312 \pm 0,0020$ \\
VT-II & $6,118 \pm 0,0008$ & $9,808 \pm 0,0012$ \\
VT-I2 & $18,561 \pm 0,0017$ & $13,35 \pm 0,0023$ \\
VB-5 & $0,793 \pm 0,0019$ & $0,419 \pm 0,0016$ \\
\hline
\end{tabular}

\section{ABTS - DPPH correlation}

A correlation analysis was performed to explore the relationships between the antioxidant parameters measured for the wine samples. The analysis of the correlation between the ABTS-DPPH tests gives us 
a value of $\mathrm{R}^{2}=0.872$ (Graph 2). This positive value of the antioxidant capacity indicates that there is a significant correlation between the tests carried out on wine samples, which allows us to reach practically similar conclusions supported by research cited by Kuskoski et al. ${ }^{16}$
The correlations obtained by linear regression between both tests (ABTS and DPPH) is significant, which indicates that the total antioxidant capacity in wines can be measured indistinctly with any of these tests.

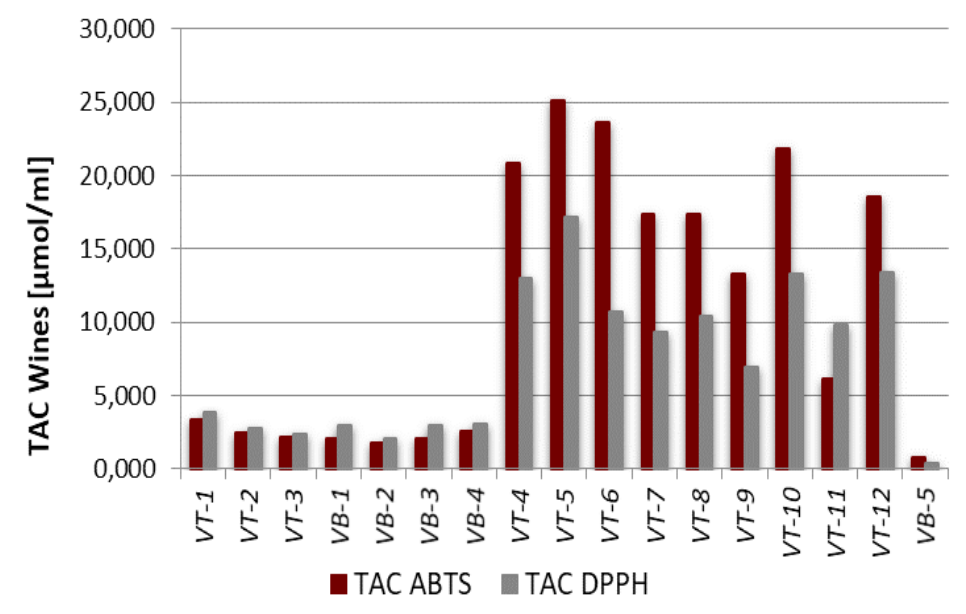

Graph I Antioxidant capacity in commercial wines.

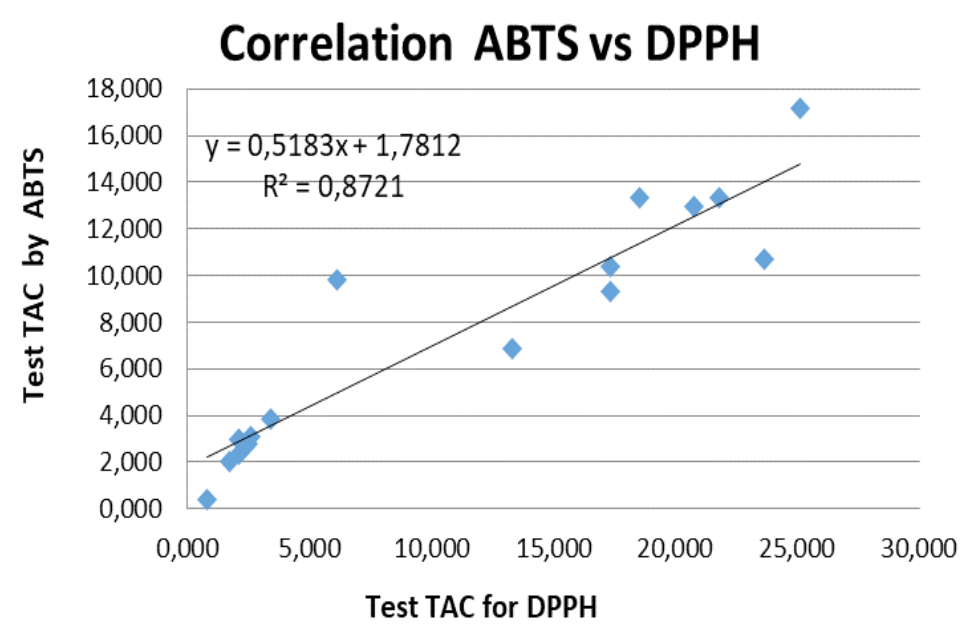

Graph 2 ABTS - DPPH test correlation.

\section{Resveratrol quantification}

In our work, the presence of trans-resveratrol was confirmed in most of the wines analyzed, with concentrations ranging between 0.77 and $3.25[\mathrm{ppm}]$ in red wines. As for white wines, these are in the range of 0.18 to 0.69 [ppm], only in a sample of white wine the presence of resveratrol was not detected Table 3. Likewise, the resveratrol analysis was carried out in wines from Argentina and Chile, which ranged from 0.54 to 0.56 and 0.43 to 0.84 [ppm] in red and white wines respectively. Comparing the results obtained for national wines and those of different origins, we observe that national wines and especially reds have a good trans-resveratrol content. Likewise, reviewing the bibliography (Table 4) of other authors, it is observed that the resveratrol content in national wines is in the ranges for both red and white wines.

Table 3 Analysis of resveratrol in commercial wines

\begin{tabular}{llllll}
\hline CODE & TRADEMARK & ORIGIN & VARIETY & YEAR & RESV [pPm] \\
\hline VT-I & CAMPOS DE SOLANA & TARIJA & CLASSIC RED WINE & 2014 & 1.99 \\
VT-2 & ARANJUEZ & TARIJA & RED TERRUÑO & 2013 & 0.77 \\
VT-3 & KOHLBERG & TARIJA & FINE RED WINE & 2014 & 1.26 \\
VB-I & ARANJUEZ & TARIJA & GREATWHITEWINE & 2013 & 0.37 \\
VB-2 & ARANJUEZ & TARIJA & WHITETERRUÑO & 2013 & 0.18 \\
VB-3 & CAMPOS DE SOLANA & TARIJA & CLASSICWHITEWINE & 2013 & 0.9 \\
\hline
\end{tabular}


Table Continued...

\begin{tabular}{|c|c|c|c|c|c|}
\hline CODE & TRADEMARK & ORIGIN & VARIETY & YEAR & RESV [ppm] \\
\hline VB-4 & KOHLBERG & TARIJA & FINE WHITE WINE & 2014 & 0.68 \\
\hline VT-4 & CAMPOS DE SOLANA & TARIJA & CABERNET SAUVIGNON & 2012 & 1.56 \\
\hline VT-5 & KOHLBERG & TARIJA & CABERNET SAUVIGNON & 2012 & 0.86 \\
\hline VT-6 & ARANJUEZ & TARIJA & CABERNET SAUVIGNON & 2012 & 2.27 \\
\hline VT-7 & LA CONCEPCION & TARIJA & CABERNET SAUVIGNON & 2013 & 3.2 \\
\hline VT-8 & 1750 & SANTA CRUZ & CABERNET SAUVIGNON & 2013 & 1.98 \\
\hline VT-9 & KOHLBERG & TARIJA & SYRAH & 2012 & 2.8 \\
\hline VT-10 & SAUSINI & TARIJA & MERLOT & 2013 & 1.48 \\
\hline VT-II & LA CONCEPCION & TARIJA & MERLOT & 2012 & 3.25 \\
\hline VT-12 & ARANJUEZ & TARIJA & TANNAT & 2012 & 1.31 \\
\hline VB-5 & LA CONCEPCION & TARIJA & SAUVIGNON BLANC & 2013 & NS \\
\hline VT-13 & LA CASONA DE MOLINA & CAMARGO & CABERNET SAUVIGNON & 2008 & 1.58 \\
\hline VB-6 & LA CASONA DE MOLINA & CAMARGO & MISSIONARY & 2009 & 2.93 \\
\hline VB-7 & LA CASONA DE MOLINA & CAMARGO & ALEXANDRIA MOSCATEL & 2014 & 0.69 \\
\hline VT-14 & 3 ZORROS & CAMARGO & VICCHOQUEÑA & & 2.36 \\
\hline V & DOÑA VITA & TARIJA & WHITE CHOLERO & & 0.37 \\
\hline W & DOÑA VITA & TARIJA & RED CHOLERO & & 0.39 \\
\hline VSA-T & SANTA ANA & ARGENTINA & CABERNET SAUVIGNON & 2012 & 0.56 \\
\hline VSA-B & SANTA ANA & ARGENTINA & SYRAH & 2012 & 0.43 \\
\hline VSC-T & SANTA CAROLINA & CHILE & CABERNET SAUVIGNON & 2012 & 0.54 \\
\hline VCD-B & CASILLERO DEL DIABLO & CHILE & SYRAH & 2011 & 0.84 \\
\hline
\end{tabular}

$\mathrm{VT}=$ red wine; $\mathrm{VB}=$ white wine

Table 4 Resveratrol content in grapes and white and red wines

\begin{tabular}{|c|c|c|c|}
\hline Source & $\begin{array}{l}\text { Trans resveratrol } \\
\text { concentration }\end{array}$ & Comments & Refs. \\
\hline Grapes & $0.16-3.54 \mu g \mathrm{~g}-1$ & $\begin{array}{l}\text { The content in wine or table grapes and white or black grapes is in } \\
\text { concentrations of } 1.5 \text { to } 7.3 \mu \mathrm{g} \text { - I }\end{array}$ & $26,28,29$ \\
\hline Red wines & $0.1-14.3 \mathrm{mg} \mathrm{I-I}$ & $\begin{array}{l}\text { cis-resveratrol, trans-piceido and cis-piceido also present, typically } \\
\text { in slightly lower concentrations }\end{array}$ & $21,23,27$ \\
\hline
\end{tabular}

\section{Conclusion}

The content of antioxidants and resveratrol in Bolivian wines shows that the antioxidant activity varies from red $>$ rosé $>$ white wines; this behavior is correct in all the analyzed wines. As expected, the resveratrol content is higher in red wines than in white wines, which is below 0.69 [ppm]. The resveratrol levels found in this work are comparable to those found by other authors (Table 4). The polyphenol content in wine can be strongly influenced not only by the vine varieties and their cultivation, but also by the form of extraction during the winemaking process, transport and storage.

\section{Acknowledgments}

The authors thank the DICyT Science and Technology Research Department of the Juan Misael Saracho Autonomous University for the support provided to the development of this work.

\section{References}

1. Rupasinghe HP, CLEGG S. Total antioxidant capacity, total phenolic content, mineral elements, and histamine concentrations in wines of different fruit sources. Journal of Food Composition and Analysis. 2007;20(2):133-137.

2. Garewall AS. Antioxidants and disease prevention". Boca Raton FL. 1997.

3. Rodrigo R, Miranda A, Vergara L. Modulation of Endogenous Antioxidant System by Wine Polyphenols in Human Disease. Clinica Chimica Acta. 2011;412:410-424.

4. Castañeda Ovando, A Pacheco-Hernández, ML Páez Hernández, et al. Chemical studies of anthocyanins: A review. Food Chemistry. 2009; 113:859-871.

5. Francis FJ. Food colorants: anthocyanins. Critical Reviews in Food Science and Nutrition. 1989;28:273-314. 
6. Marco Taquichiri, Ruth Ayarde, Pastor Gutierrez, et al. High Levels of Resveratrol in Grapes Cultivated at High Altitude Valleys in Bolivia. International Journal of Fruit Science. 2014;14:1-16.

7. Filip V, Plocková M, Šmidrkal J, et al. Resveratrol and its antioxidant and antimicrobial effectiveness. Food Chem . 2003;83(4):585-593.

8. Burkitt MJ, Duncan J. Effects of trans-resveratrol on copper-dependent hydroxyl-radical formation and DNA-damage: evidence for hydroxyl radical scavenging and a novel, glutathione-sparing mechanism of action. Arch Biochem Biophys. 2000;381(2):253-263

9. Šmidrkal J, Filip V, Melzoch K, et al. Resveratrol. Chem Listy. 2001;95(10):602-609.

10. Stervbo U, O Vang, C Bonneses. A Review of the content of the putative chemopreventive phytoalexin resveratrol in red wine. Food Chem. 2007;101:449-457.

11. Barger JL, Kayo T, Vann JM, et al. A low dose of dietary resveratro partially mimics caloric restriction and retards aging parameters in mice. PloS ONE. 2007;2008;3(6):e2264.

12. Peñarrieta JM, JA Alvarado, B Åkesson, et al. Total antioxidant capacity and content of flavonoids and other phenolic compounds in Canihua (Chenopodium pallidicaule): Andean pseudocereal. Mol Nutr Food Res. 2008;52:708-717.

13. Bustos AS, Calisaya JC, Paredes C, et al. Cuantificación de resveratrol en vinos mediante HPLC. Rev Bol Quim. 2012;29(2):164-169.

14. Alvarado JA. Protocolos de CEIQA. Ciencias Puras, Carrera Química, UMSA (2da versión). 2012.

15. Cristea D, Bereau I, Vilarem G. Identification and quantitative HPLC analysis of the main flavonoids present in weld (Reseda luteola L.). Dyes and Pigments. 2003;57:267-272.

16. Kuskoski EM, Asuero AG, Troncoso A, et al. Aplicación de diversos métodos químicos para determinar actividad antioxidante en pulpa de frutos. Ciênc Tecnol Aliment. 2005;25(4):726-732.
17. M Seigneur, J Bonnet, B Dorian D, et al. Screening for Cervical Cancer. $J$ Appl Cardiol. 1990;5:215-222.

18. LL Creasy, M Coffee. J Amer Soc Hort Sci. 1988;113:230-234.

19. P Jeandet, R Bessis, B.Gautheron. Amer J Enol Viticult. 1991;42:41-46.

20. EH Siemann, LL Creasy. Amer J Enol Viticult. 1992;43:49-52.

21. Soleas GJ, Diamandis EP, Goldberg DM. Resveratrol: a molecule whose time has come? And gone? Clin. Biochem. 1997;30:91-113.

22. Rattan SI. Aging, anti-aging, and hormesis. Mech Ageing Dev. 2004;125:285-289.

23. Goldberg DM. A global survey of trans-resveratrol concentrations in commercial wines. Am J Enol Vitic. 1995;46:159-165.

24. Kiraly-Veghely Z, Tyihak E, Albert L, et al. Identification and measurement of resveratrol and formaldehyde in parts of white and blue grape berries. Acta Biol Hung. 1998;49:281-289.

25. Ribeiro de Lima MT, P Waffo-Téguo, P L Teissedre, et al. Determination of stilbenes (trans-astringin, cis- and trans-piceid, and cis- and transresveratrol) in Portuguese wines. J Agric Food Chem. 1990;47:26662670 .

26. Burns J, Yokota T, Ashihara H, et al. Plant foods and herbal sources of resveratrol. J Agric Food Chem. 2002;50:3337-3340.

27. Vitrac X. Determination of stilbenes ( $\delta$-viniferin, trans-astringin, transpiceid, cis- and trans-resveratrol, $\varepsilon$-viniferin) in Brazilian wines. $J$ Agric Food Chem. 2005;53:5664-5669.

28. Soleas GJ. A derivatized gas chromatographic mass spectrometric method for the analysis of both isomers of resveratrol in juice and wine. Am J Enol Vitic. 1995;46:346-352.

29. Rimando AM, Kalt W, Magee JB, et al. Resveratrol, pterostilbene, and piceatannol in vaccinium berries. J Agric Food Chem. 2004;52:47134719 